\section{Iceberg Lettuce Breeding Lines with Resistance to Verticillium Wilt Caused by Race 1 Isolates of Verticillium dahliae}

\author{
Ryan J. Hayes ${ }^{2}$ \\ U.S. Department of Agriculture, Agricultural Research Service, Crop \\ Improvement and Protection Unit, 1636 E. Alisal Street, Salinas, CA 93905 \\ Karunakaran Maruthachalam \\ Department of Plant Pathology, University of California, Davis, clo U.S. \\ Agricultural Research Station, 1636 E. Alisal Street, Salinas, CA 93905 \\ Gary E. Vallad ${ }^{1}$ \\ Department of Plant Pathology, University of California, Davis, c/o U.S. \\ Agricultural Research Station, 1636 E. Alisal Street, Salinas, CA 93905
}

Steven J. Klosterman and Ivan Simko

U.S. Department of Agriculture, Agricultural Research Service, Crop Improvement and Protection Unit, 1636 E. Alisal Street, Salinas, CA 93905

Yaguang Luo

U.S. Department of Agriculture, Agricultural Research Service, Food Quality Lab, Henry A. Wallace Beltsville Agricultural Research Center, Building 002, 10300 Baltimore Ave., Beltsville, MD 20705

\section{Krishna V. Subbarao}

Department of Plant Pathology, University of California, Davis, c/o U.S. Agricultural Research Station, 1636 E. Alisal Street, Salinas, CA 93905

Additional index words. Lactuca sativa L., cultivar, variety, disease resistance, salad-cut lettuce, vegetable breeding, post-harvest quality

The Agricultural Research Service, U.S. Department of Agriculture and the University of California, Davis, announce the release of two breeding lines of lettuce (Lactuca sativa L.). Lines RH08-0472 and RH08-0475 are F $_{9}$ iceberg-type lettuce breeding lines with resistance to verticillium wilt caused by $V$. dahliae. They were selected from the cross 'Tiber' $x$ ('La Brillante' $\times$ 'Pacific'). Resistance is derived from 'La Brillante', a Batavia-type lettuce cultivar with resistance to Race 1 isolates of $V$. dahliae. These breeding lines are suitable for commercial production in both $V$. dahliaeinfested and non-infested fields. They are being released for commercialization of verticillium wilt-resistant iceberg cultivars and for use as parents in further breeding of resistant cultivars.

Received for publication 4 Jan. 2011. Accepted for publication 11 Jan. 2011.

This research was supported by the California Leafy Greens Research Program.

We thank Taylor Farms for cooling and shipping lettuce from whole head post-harvest evaluations. ${ }^{1}$ Current address: University of Florida, Gulf Coast Research and Education Center, 14625 CR 672, Wimauma, FL 33598

${ }^{2}$ To whom reprint requests should be addressed; e-mail Ryan.Hayes@ars.usda.gov.
They have been deposited in the National Plant Germplasm System as W6 39944 (RH080472) and W6 39945 (RH08-0475).

Verticillium wilt, caused by the soilborne fungus Verticillium dahliae Kleb., is a serious soilborne disease affecting a broad range of economically important crops (Pegg and Brady, 2002). Lettuce (Lactuca sativa L.) was not considered a host for $V$. dahliae until the mid1990s, when the disease was discovered in coastal production districts of California (Subbarao et al., 1997). The disease has subsequently spread within coastal California (Atallah et al., 2010) and has also been detected on lettuce in the Mediterranean basin (Garibaldi et al., 2007; Ligoxigakis et al., 2002). Verticillium dahliae is seed-transmitted in lettuce and other vegetable crops grown in rotation with lettuce, raising concerns regarding its spread to other lettuce production areas (Atallah et al., 2010; Vallad et al., 2005). Although all types of lettuce are susceptible, verticillium wilt is most damaging to icebergtype cultivars. Plants often remain symptomless until they near harvest maturity, at which time the symptoms develop quickly. Basal or "wrapper leaves" that completely cover the outer part of the head wilt and then collapse as the disease progresses, leading to premature plant death and an unharvestable head. Other key foliar symptoms include stunting, defoliation, and other developmental abnormalities. Before the onset of foliar symptoms, the vascular discoloration of root and stem tissues, revealed by vertical sectioning of the plant, are the only other diagnostic features.

Host resistance is the best long-term control method in lettuce, because current cultural and chemical control methods are cost-prohibitive, potentially damaging to the environment, or of limited feasibility (Subbarao et al., 1997). Two pathogenic races (Race 1 and Race 2) of $V$. dahliae on lettuce have been described. The Batavian cultivar La Brillante and several other heirloom cultivars are resistant to Race 1 isolates, whereas no known source of resistance to Race 2 isolates has been reported (Hayes et al., 2007; Vallad et al., 2006). Race 1 resistance in 'La Brillante' is complete (no symptom development) (Vallad and Subbarao, 2008) and continues to be effective in grower fields (Hayes et al., 2007). We are reporting on the development of iceberg breeding lines RH08-0472 and RH08-0475, which have resistance to Race 1 isolates of $V$. dahliae inherited from 'La Brillante'.

\section{Origin and Development}

RH08-0472 and RH08-0475 were selected from the cross 'Tiber' $\times$ 01-1071; 01-1071 was an $\mathrm{F}_{5}$ line derived from 'Pacific' $\times$ ' $\mathrm{La}$ Brillante'. Breeding line 01-1071 is notable because it is the source line from which the verticillium wilt-resistant breeding lines $\mathrm{RH} 05$ 0336, RH05-0339, and RH05-0340 were selected and released in 2006 (Hayes et al., 2006). RH05-0336, RH05-0339, and RH05-0340 were the first iceberg lines bred for verticillium wilt resistance but were not suitable for commercial production. 'La Brillante' is a yellowgreen Batavia-type cultivar that is not used for commercial production in California. The origin of 'La Brillante' is unknown but has been characterized as highly susceptible to the calcium deficiency-related disorder tipburn (data not shown; see Ryder, 1999, for a review of tipburn in lettuce), partially resistant to the disease big-vein caused by the soilborne virus Mirafiori lettuce big-vein virus (Ryder and Robinson, 1995), resistant to the disease dieback caused by the soilborne viruses in the Tombusviridae family (Simko et al., 2009), and has a short shelf life after processing into salad (Hayes and Liu, 2008). 'Tiber' and 'Pacific' are modern iceberg-type cultivars developed by the USDA and are broadly adapted for coastal California production conditions. 'Pacific' was specifically selected for resistance to big-vein disease (Ryder and Robinson, 1991), whereas 'Tiber' was developed with improved resistance to tipburn (Ryder and Waycott, 1998). 'Pacific' and 'Tiber' are susceptible to verticillium wilt (Hayes et al., 2007).

Lettuce $(2 \mathrm{n}=2 \mathrm{x}=18)$ is an autogamous species and all seed was produced by allowing greenhouse-grown plants to self-pollinate; seed harvested from individual plants was kept separate unless otherwise noted. The general breeding strategy for developing verticillium wilt-resistant icebergs was to select between 
families for resistance to verticillium wilt and then between and within resistant families for superior horticultural characteristics. All evaluations and selections were conducted in infested grower field experiments located in Watsonville, CA. The race structure of $V$. dahliae is not precisely known in these sites, but the sites are believed to be predominantly infested with Race 1 strains (Hayes et al., 2007). However, the existence of some Race 2 isolates has been established at these sites (Maruthachalam et al., 2010). Resistance evaluations were conducted by uprooting 10 randomly selected plants from test plots of 40 to 100 plants, vertically sectioning the root and crown, and assessing the plant for root discoloration and foliar symptoms typical of verticillium wilt. Single plant selections with industryacceptable iceberg-type head characteristics were subsequently taken from only the families deemed resistant (typically less than 10\% disease incidence) and repotted in an isolated greenhouse for seed production. Selection within families for resistance was not technically possible, because the assay is destructive. However, wilting plants with Verticillium like foliar symptoms were avoided. RH08-0472 and $\mathrm{RH} 08-0475$ are derived from a single $\mathrm{F}_{5}$ plant developed using the breeding scheme described. This plant belonged to a line that appeared to be fixed for resistance beginning in the $\mathrm{F}_{4}$ generation. In 2007, a $\mathrm{F}_{5: 7}$ seed lot was developed by massing several $\mathrm{F}_{6}$ plants grown under non- $V$. dahliae-infested conditions and had limited testing for adaptation in testing was conducted in 2007 and 2008, because all $V$. dahliae-infested field sites were either fumigated or unavailable. Regardless, slight variations in maturity were noticed among $\mathrm{F}_{7}$ plants in a Salinas, $\mathrm{CA}$, non-infested field experiment, and single plant selections were made to obtain the $\mathrm{F}_{7: 8}$ lines RH08-0472 and RH08-0475. Adaptation and disease resistance characterization were subsequently conducted in 2009 and 2010 using $\mathrm{F}_{7: 8}$ and $\mathrm{F}_{7: 9}$ seed, respectively, that was produced in non- $V$. dahliae-infested field sites.

\section{Description}

Characterization of RH08-0472 and RH080475 in field experiments was largely done in comparison with 'Salinas 88 ', a cultivar developed from backcrossing the $m o l^{2}$ allele for Lettuce mosaic virus resistance into the cultivar Salinas (Ryder, 1991). RH08-0472 and RH08-0475 closely resemble 'Salinas 88 ' as well as 'Tiber' and 'Pacific' (pictures of RH08$0472<$ http://www.ars-grin.gov/cgi-bin/npgs/ acc/search.pl?accid=W6+39944>; pictures of RH08-0475 < http://www.ars-grin.gov/cgi-bin/ npgs/acc/search.pl?accid=W6+39945>). The outer leaves are dull green, whereas the internal leaves are light yellow. Leaves are wider than they are long with wavy margins, moderate savoy, and minimal undulation. The apex is truncate to emarginate or notched. Heads are firm at maturity, slightly wider than tall, and occasionally oblong when viewed from the top. Ribs are flat to occasionally protruding. Days to 2008 as breeding line RH07-0341. No disease market maturity, initiation of bolting, anthesis, and seed set are equivalent to 'Salinas $88^{\prime}$. Seeds are black.

\section{Disease resistance, horticultural characteristics, yield, and post-harvest quality}

Field experiments, data collection, and methods. Adaptation, yield, horticultural characters, post-harvest quality, and resistance to physiological defects were assessed in field experiments having diverse locations and planting dates. Resistance to the diseases verticillium wilt, big-vein, and downy mildew (caused by the Oomycete Bremia lactucae) was assessed in multiple replicated field experiments or greenhouse experiments. 'Salinas 88', the breeding lines parent's 'Pacific' and 'Tiber' as well as known control cultivars were included in experiments as needed. Production conditions for field experiments were standard for coastal California (Ryder, 1999), except where specified.

The verticillium wilt resistance of RH080472 and RH08-0475 was assessed in four replicated experiments at a field site infested solely with a Race 1 isolate (VdLs16) of $V$. dahliae located in Salinas, CA. Resistance to Race 2 isolate VdLs 17 was also assessed in a single replicated greenhouse experiment using the methods of Hayes et al. (2007). In all experiments, Verticillium wilt disease incidence (DI) was assessed using the methods of Hayes et al. (2007).

Verticillium wilt DI, horticultural characteristics, and yield were also assessed in two unreplicated infested experiments conducted in grower field sites in Salinas, CA (Trials 1 and 2 in Tables 1 and 2). The exact $V$. dahliae race structure is unknown at these locations but is believed to be predominated by Race 1 strains based on previous field experiments (Hayes and Subbarao, unpublished results). Yield was assessed as percent harvestable heads and subsequently transformed to cartons per acre. The horticultural characters assessed include head weight $(\mathrm{g})$, head height $(\mathrm{cm})$, head diameter $(\mathrm{cm})$, core height $(\mathrm{cm})$, and maturity $(1=$ immature through $5=$ overmature $)$ and percent tipburn. Data were collected on two evaluation dates separated by 1 week.

Using field sites not infested with $V$. dahliae, two replicated experiments in Soledad, CA (Trials 3 and 4 on Table 2) and two replicated experiments located at the USDA research farm

Table 1. Verticillium wilt disease incidence (DI) in two lettuce iceberg breeding lines and cultivars caused by Verticillium dahliae in replicated and unreplicated 2009 and 2010 field experiments in Salinas, CA.

\begin{tabular}{|c|c|c|c|c|c|}
\hline & & cated field e & & Un & xpt. \\
\hline & arti & infested wit & & naturally & wer field \\
\hline & Median & Maximum & & Trial 1 & Trial 2 \\
\hline Line & DI & DI & $\mathrm{RE}^{\mathrm{y}}$ & DI & DI \\
\hline La Brillante & 0.0 & 0.3 & $0.29 \mathrm{a}$ & 0.0 & 0.0 \\
\hline Salinas 88 & 0.6 & 1.0 & $0.82 \mathrm{~b}$ & 0.8 & 1.0 \\
\hline Tiber & 0.7 & 1.0 & $0.79 \mathrm{~b}$ & & \\
\hline RH08-0472 & 0.1 & 0.6 & $0.37 \mathrm{a}$ & 0.0 & 0.0 \\
\hline RH08-0475 & 0.0 & 0.4 & $0.31 \mathrm{a}$ & 0.0 & 0.0 \\
\hline
\end{tabular}

${ }^{z}$ Results from four experiments. Field was infested with Race 1 isolate VdLs16.

${ }^{y}$ Relative effect calculated from rank analysis of percent infected data. RE followed by different letters indicate significant differences.

in Salinas, CA (Trials 5 and 6 on Table 2) were conducted to assess yield, horticultural characteristics, and tipburn resistance using the method and variables previously discussed. In addition, post-harvest quality of whole heads and minimally processed salad was assessed using lettuce harvested from the USDA research farm. Shelf life of minimally processed salad was evaluated using the methods of Hayes and Liu (2008) and rated on a scale of $0 \%$ decay to $100 \%$ decay. The quality of whole heads after shipment to markets (arrival quality) was assessed for Salinas 88 and RH08-0472. RH08-0475 was not included as a result of an insufficient number of heads. Twenty-four heads (pooled from all plots) per breeding line or cultivar were harvested on 10 Aug. 2010, packed in cartons, vacuum-cooled, and transported in a refrigerated truck to Beltsville, MD. On arrival, the heads were stored at $5{ }^{\circ} \mathrm{C}$, and each head was rated by three trained evaluators on 24 Aug. 2010 using a 5-point scale with 0 corresponding to no apparent decay and 4 corresponding to greater than $75 \%$ decay. Each head was treated as a replicate for data analysis.

The incidence of big-vein symptomatic plants was recorded in the Soledad, CA, field experiments and resistance to downy mildew in two replicated field experiments in Salinas, CA. Big-vein resistance was assessed as the percentage of big-vein symptomatic plants, whereas downy mildew severity was assessed on a scale of $0=$ no disease through $5=$ severe disease.

Statistical analysis of data from replicated experiments was conducted using PROC Mixed of SAS (Version 9.2; SAS Institute, Inc., Cary, NC) following the recommendations of Littell et al. (2006). Mean comparisons were adjusted using the Tukey option. Percent big-vein data were analyzed on the arcsine ack and backformed and reported on tables as disease rating (DR). Verticillium DI and DS data were analyzed using ranked data Procedure in SAS Institute, Inc., Version 9.2) (Brunner et al., 2002; Shah and Madden 2004); relative effects and cultivars and breeding lines were using the LD_CI macro as done with other verticillium wilt resistance experiments (Hayes et al., 2007). The line $\times$ experiment interaction was not significant for replicated verticillium wilt field experiments, so the data were pooled into a single analysis. No statistical comparisons were conducted with unreplicated data. 
Table 2. Horticultural characteristics, yield, percent tipburn, and post-harvest quality of lettuce breeding lines and cultivars in unreplicated Verticillium dahliaeinfested field experiments in Salinas, CA, and replicated non-infested field experiments in Soledad, CA, and Salinas, CA, conducted between 2008 and 2010.

\begin{tabular}{|c|c|c|c|c|c|c|c|c|c|c|c|}
\hline \multirow[b]{2}{*}{ Line } & \multirow[b]{2}{*}{$\begin{array}{c}\text { Harvest } \\
\text { date }\end{array}$} & \multicolumn{7}{|c|}{ Horticultural characteristics and yield } & \multirow{2}{*}{$\begin{array}{c}\text { Percent } \\
\text { tipburn } \\
(\%)\end{array}$} & \multicolumn{2}{|c|}{ Post harvest quality } \\
\hline & & $\begin{array}{l}\text { Head } \\
\text { wt }(\mathrm{g})\end{array}$ & $\begin{array}{c}\text { Head } \\
\text { ht }(\mathrm{cm})\end{array}$ & $\begin{array}{c}\text { Head } \\
\text { width }(\mathrm{cm})\end{array}$ & $\begin{array}{l}\text { Core ht } \\
(\mathrm{cm})\end{array}$ & $\begin{array}{c}\text { Maturity } \\
1-5^{z}\end{array}$ & $\begin{array}{c}\text { Percent } \\
\text { harvestable }\end{array}$ & $\begin{array}{c}\text { Cartons/ } \\
\text { acre }^{\mathrm{y}}\end{array}$ & & $\begin{array}{c}\text { Salad } \\
\text { shelf life }^{\mathrm{x}}\end{array}$ & $\begin{array}{l}\text { Whole head } \\
\text { arrival quality }\end{array}$ \\
\hline \multicolumn{12}{|c|}{ Trial 1: unreplicated V. dahliae-infested grower trial, two seed lines on 102-cm wide beds in Salinas, CA } \\
\hline La Brillante & 9.09 .10 & & & & & & & & 0 & & \\
\hline La Brillante & 9.16 .10 & & & & & & & & 100 & & \\
\hline RH08-0472 & 9.09 .10 & 653 & 13.1 & 16.0 & 2.6 & 4.5 & 75 & 813 & 0 & & \\
\hline RH08-0472 & 9.16 .10 & 741 & 13.1 & 16.5 & 7.1 & 4.5 & 60 & 650 & 10 & & \\
\hline RH08-0475 & 9.09 .10 & 577 & 12.1 & 16.3 & 2.8 & 3.0 & 67 & 726 & 0 & & \\
\hline RH08-0475 & 9.16 .10 & 889 & 12.5 & 17.8 & 5.3 & 4.5 & 84 & 910 & 20 & & \\
\hline Salinas 88 & 9.09 .10 & 623 & 12.3 & 16.4 & 2.9 & 3.0 & 59 & 639 & 0 & & \\
\hline Salinas 88 & 9.16 .10 & 623 & 12.7 & 15.6 & 4.2 & 4.5 & 45 & 488 & 30 & & \\
\hline
\end{tabular}

Trial 2: unreplicated $V$. dahliae-infested grower trial, five seed lines on 204-cm wide beds in Salinas, CA

La Brillante $\quad 10.01 .10$

La Brillante $\quad 10.08 .10$

RH08-0472

RH08-0472 10.08 .10

RH08-0475 $\quad 10.01 .10$

RH08-0475 10.08.10

Salinas 88

10.01 .10

$511 \quad 11.6$

$666 \quad 12.2$

$451 \quad 11.4$

11.4
12.0

$\begin{array}{ll}621 & 12.0 \\ 526 & 12.8\end{array}$

Salinas 88

10.08 .10

479

12.6

17.1
16.3
15.0
16.2
15.6
15.7

$\begin{array}{ll}2.7 & 2.5 \\ 3.4 & 4.0 \\ 2.1 & 2.0 \\ 3.7 & 4.0 \\ 2.8 & 2.5 \\ 3.4 & 4.0\end{array}$

47
34
26
58
43
8

$\begin{array}{ll} & 0 \\ 636 & 0 \\ 460 & 0 \\ 352 & 0 \\ 785 & 0 \\ 582 & 0 \\ 108 & 0 \\ & 0\end{array}$

Trial 3: replicated non-infested grower trial, two seed lines on 102-cm wide beds in Soledad, CA

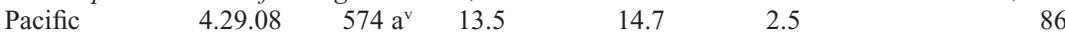

$\begin{array}{llllll}\text { RH07-0341 } & 4.29 .08 & 782 \mathrm{~b} & 12.9 & 14.3 & 3.0\end{array}$

$\begin{array}{llllll}\text { Salinas } 88 & 4.29 .08 & 629 \mathrm{ab} & 13.1 & 14.1 & 3.4\end{array}$

Tiber $\quad 4.29 .08 \quad 534 \mathrm{ab} \quad 13.2 \quad 13.1$

3.4

65
81

81
67

$\begin{array}{ll}932 & 0 \\ 704 & 0 \\ 878 & 0 \\ 726 & 0\end{array}$

Trial 4: replicated non-infested grower trial, two seed lines on 102-cm wide beds in Soledad, CA

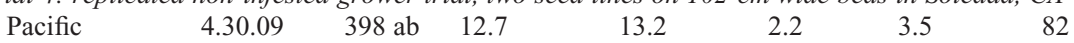

$\begin{array}{lllll}\mathrm{RH} 08-0472 & 4.30 .09 & 611 \mathrm{~b} & 13.2 & 13.0\end{array}$

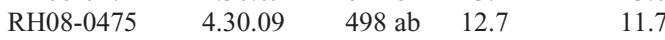

Salinas $88 \quad 4.30 .09 \quad 323$ a $\quad 11.6 \quad 12.5$

$\begin{array}{llll}\text { Tiber } & 4.30 .09 & 412 \mathrm{ab} & 11.7\end{array}$

$\begin{array}{lll}2.2 & 3.5 & 82 \\ 2.8 & 3.0 & 83 \\ 2.9 & 3.5 & 70 \\ 2.4 & 3.3 & 74 \\ 2.2 & 3.2 & 63\end{array}$

$C A$
82
83
70
74
63

$\begin{array}{ll}888 & 0 \\ 899 & 0 \\ 758 & 0 \\ 802 & 0 \\ 683 & 0\end{array}$

Trial 5: replicated non-infested USDA trial, two seed lines on 102-cm wide beds in Salinas, CA

\begin{tabular}{|c|c|c|c|c|c|c|c|c|c|c|}
\hline Tiber & 7.10 .09 & 826 & 12.8 & 15.8 & 2.8 & 3.2 & 82 & 888 & 5 & \\
\hline Pacific & 7.10 .09 & 818 & 14.4 & 16.4 & 3.0 & 3.0 & 78 & 845 & 5 & \\
\hline Salinas 88 & 7.10 .09 & 701 & 14.0 & 16.2 & 3.1 & 2.8 & 82 & 888 & 5 & $1.4 \mathrm{a}$ \\
\hline RH08-0472 & 7.10 .09 & 932 & 12.7 & 17.7 & 2.6 & 2.5 & 77 & 834 & 30 & $3.3 \mathrm{a}$ \\
\hline RH08-0475 & 7.10 .09 & 827 & 12.9 & 16.8 & 2.7 & 3.0 & 77 & 834 & 20 & $3.3 \mathrm{a}$ \\
\hline Triple Threat & 7.10 .09 & & & & & & & & & $10.0 \mathrm{~b}$ \\
\hline
\end{tabular}

Trial 6: replicated non-infested USDA trial, two seed lines on 102-cm wide beds in Salinas, CA

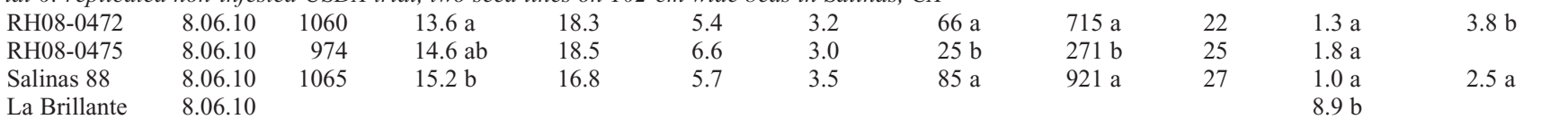

${ }^{\mathrm{z}}$ Head maturity visually rated as 1 for immature to 5 for overmature.

${ }^{y}$ Assumes 26,000 plants per acre on 102-cm wide beds and 32,500 plants per acre on 204-cm wide beds.

xThe amount of salad tissue decay was visually evaluated on a scale of 1 to 10 , in which 1 is no obvious decay and 10 is complete decay.

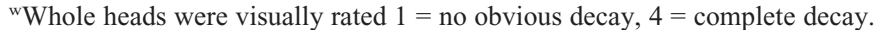

${ }^{v}$ Means followed by different letters indicate a significant difference at $P<0.05$. The means are otherwise not significantly different.

Verticillium wilt resistance. RH08-0472 and RH08-0475 have levels of resistance to verticillium wilt comparable to 'La Brillante', whereas 'Salinas 88' and 'Tiber' are highly susceptible. In four replicated field experiments infested with Race 1 V. dahliae isolate VdLs16, the disease incidence of 'La Brillante', RH080472, and RH08-0475 was significantly lower compared with 'Salinas 88' and 'Tiber' (Table 1). In two unreplicated infested grower field experiments, no root or foliar symptoms of verticilium wilt were observed in 'La Brillante', RH08-0472, or RH08-0475 (Table 1, Trials 1 and 2). In the susceptible cultivar Salinas 88 , DI was $80 \%$ and $100 \%$ in Trials 1 and 2, respectively (Table 1 ).

Yield and horticultural performance in infested and non-infested field experiments.
RH08-0472 or RH08-0475 produce commercially acceptable yields with good horticultural characteristics when grown in infested or noninfested fields and have a range of adaptation to production methods and harvest dates equivalent to 'Salinas 88'. In two unreplicated field experiments conducted in $V$. dahliae-infested grower fields in Salinas, CA (Table 2, Trials 1 and 2), yield, head weight, head height, and head width were generally unchanged or increased for RH08-0472 and RH08-0475 between the first and second harvest dates (Table 2 , Trials 1 and 2). In contrast, these same variables were generally unchanged or decreased for 'Salinas $88^{\circ}$ ' as a result of the onset of verticillium wilt symptoms. For all lines, core height and maturity generally increased from the first to second harvest date.
In four replicated field experiments conducted in non-infested fields located in Soledad, $\mathrm{CA}$, and Salinas, CA, and with harvest dates ranging from late April to early August, yields (percent harvestable and cartons per acre) of the breeding lines were generally similar to 'Salinas 88', 'Pacific', and 'Tiber' (Table 2, Trials 3 to 6). In a single experiment in Salinas, CA, RH08-0475 had yields significantly lower than 'Salinas 88' (Table 2, Trial 6). The experiment was highly unusual as a result of the relatively advanced maturity of 'Salinas 88 ' and late maturity of RH08-0475 combined with an undetermined bottom rot that prevented the option of a later harvest date. Regardless, this experiment demonstrates that environments may exist that can result in reduced yields for at least RH08-0475. RH08-0472 or RH08-0475 
Table 3. Big-vein disease rating in lettuce breeding lines and cultivars in replicated 2008 and 2009 infested field experiments in Soledad, CA, and downy mildew severity in two replicated field experiments conducted in 2010 in Salinas, CA.

\begin{tabular}{|c|c|c|c|c|c|c|}
\hline \multirow[b]{4}{*}{ Line } & \multicolumn{4}{|c|}{ Big-vein incidence } & & \\
\hline & \multicolumn{2}{|c|}{2008} & \multicolumn{2}{|c|}{2009} & \multirow{2}{*}{\multicolumn{2}{|c|}{ Downy mildew ${ }^{\mathrm{y}}$}} \\
\hline & \multirow{2}{*}{$\begin{array}{c}\text { Number } \\
\text { tested }\end{array}$} & \multirow{2}{*}{$\begin{array}{c}\text { Mean } \\
\text { DR }^{z}\end{array}$} & \multirow{2}{*}{$\begin{array}{c}\text { Number } \\
\text { tested }\end{array}$} & \multirow{2}{*}{$\begin{array}{c}\text { Mean } \\
\text { DR }\end{array}$} & & \\
\hline & & & & & Severity & rAUDPC \\
\hline Great Lakes 65 & 141 & $0.79^{x}$ & 118 & $0.60^{\mathrm{x}}$ & & \\
\hline Pacific & 158 & 0.40 & 129 & 0.24 & & \\
\hline Tiber & 44 & 0.54 & 120 & 0.38 & 2.9 & 58.6 \\
\hline Salinas 88 & 114 & 0.33 & 124 & 0.38 & 4.5 & 68.6 \\
\hline La Brillante & & & & & $1.0^{\mathrm{w}}$ & $13.6^{\mathrm{w}}$ \\
\hline RH07-0341 & 104 & 0.54 & & & & \\
\hline RH08-0472 & & & 42 & 0.31 & 3.0 & 48.6 \\
\hline RH08-0475 & & & 43 & 0.30 & 2.8 & 44.3 \\
\hline
\end{tabular}

${ }^{\mathrm{z}} \mathrm{DR}=$ disease rating, backtransformed values from analysis of arcsine transformed percentage big-vein symptomatic plants data.

yDowny mildew resistance was assessed in two independent 2010 field experiments located in Salinas, CA, using a scale of 0 for no disease to 5 for severe disease. Severity was scored 27 Oct. 2010 in the first field experiment. Relative area under the disease progress curve (rAUDPC) was calculated in a second experiment using four severity assessment dates spaced $7 \mathrm{~d}$ apart beginning on 22 Sept. 2010 and ending on 13 Oct. 2010.

xSignificantly higher disease rating than 'Pacific'.

wSignificantly lower than 'Salinas 88'.

may have the potential for slightly larger and heavier heads compared with 'Pacific' and 'Salinas 88'. In two experiments harvested in April, head weights were significantly greater than 'Pacific' and 'Salinas 88'. Head height, head width, core height, and maturity were not significantly different from the commercial cultivars tested.

Tipburn resistance and post-harvest quality. Tipburn incidence was recorded in two infested and four non-infested field experiments. On the 16 Sept. 2010 harvest date of unreplicated Trial 1 , the tipburn incidence was $100 \%, 10 \%, 20 \%$, and 30\% for 'La Brillante', RH08-0472, RH080475, and 'Salinas 88', respectively (Table 2). In Trials 5 and 6, the tipburn incidence was not significantly different between the breeding lines and the control cultivars Tiber, Pacific, and Salinas 88 (Table 2). No tipburn was observed in Trials 2, 3 and 4 (Table 2). The shelf life of minimally processed salad of RH080472, RH08-0475, and 'Salinas 88' was not significantly different (Table 2). However, 'Salinas 88', RH08-0472, and RH08-0475 were significantly better than the poor shelf life controls 'Triple Threat' (romaine lettuce) and 'La Brillante' (Table 2). Considering the tipburn resistance and shelf life of RH08-0472 and RH08-0475, these lines appear to be suitable for use in the minimally processed salad market. In a single field experiment, the whole head arrival quality of RH08-0472 was significantly lower compared with 'Salinas 88', a cultivar with exceptional arrival quality (E.J. Ryder, personal communication) (Table 2, Trial 6). These results indicate that commercial production of $\mathrm{RH} 08$ 0472 and RH08-0475 should use methods that will ensure the highest possible arrival quality of whole heads.

Resistance to big-vein disease and downy mildew. The resistance to big-vein in RH080472, and RH08-0475 is similar to 'Salinas 88' and 'Tiber', which in these field experiments was not significantly different from 'Pacific'
(Table 3). The big-vein disease rating in all these lines was significantly less than the susceptible control 'Great Lakes 65' (Table 3). The downy mildew severity in 'La Brillante' was significantly lower than 'Salinas 88' (Table 3). The downy mildew severity scores of RH080472 and RH08-0475 were lower than 'Salinas 88 ', but the difference was not significant (Table 3).

\section{Availability}

Limited seed samples of RH08-0472 and RH08-0475 as well as RH05-0336, RH050339, and RH05-0340 are available for distribution to all interested parties for research purposes. These lines are being publically released with no IP protection for the development and commercialization of new cultivars by seed companies, universities, NGOs, or other bona fide private or public research organizations. Samples were deposited in the National Plant Germplasm System as W6 39944 (RH08-0472) and W6 39945 (RH08-0475). It is requested that appropriate recognition be made if the breeding lines contribute to research or the development of new germplasm, breeding lines, or cultivars. Written requests should be sent to Dr. Ryan Hayes, USDA-ARS, 1636 E. Alisal Street, Salinas, CA 93905 or sent through e-mail (Ryan.Hayes@ars.usda.gov).

\section{Literature Cited}

Atallah, Z.K., K. Maruthachalam, L. du Toit, S.T. Koike, R.M. Davis, S.J. Klosterman, R.J. Hayes, and K.V. Subbarao. 2010. Population analyses of the vascular plant pathogen Verticillium dahliae detect recombination and transcontinental gene flow. Fungal Genet. Biol. 47:416422.

Brunner, E., S. Domhof, and F. Langer. 2002. Nonparametric analysis of longitudinal data in factorial experiments. John Wiley \& Sons, New York, NY.
Garibaldi, A., G. Gilardi, and M.L. Gullino. 2007. First report of verticillium wilt caused by Verticillium dahliae on lettuce in Italy. Plant Dis. 91:770.

Hayes, R.J. and Y.B. Liu. 2008. Genetic variation for shelf-life of salad-cut lettuce in modifiedatmosphere environments. J. Amer. Soc. Hort. Sci. 133:228-233.

Hayes, R.J., G.E. Vallad, E.J. Ryder, and K.V. Subbarao. 2006. Release of iceberg lettuce germplasm with resistance to verticillium wilt. Agricultural Research Service, U.S. Dept. of Agriculture

Hayes, R.J., G.E. Vallad, Q.-M. Qin, R.C. Grube, and K.V. Subbarao. 2007. Variation for resistance to verticillium wilt in lettuce (Lactuca sativa L.). Plant Dis. 91:439-445.

Ligoxigakis, E.K., D.J. Vakalounakis, and C.C. Thanassoulopoulos. 2002. Weed hosts of Verticillium dahliae in Crete: Susceptibility, symptomatology and significance. Phytoparasitica 30: 511-518.

Littell, R.C., G.A. Milliken, W.W. Stroup, R.D. Wolfinger, and O. Schabenberger. 2006. SAS for mixed models. SAS Institute Inc, Cary, NC.

Maruthachalam, K., Z.K. Atallah, G.E. Vallad, S.J. Klosterman, R.J. Hayes, R.M. Davis, and K.V. Subbarao. 2010. Molecular variation among isolates of Verticillium dahliae and PCRbased differentiation of races. Phytopathology 100:1222-1230.

Pegg, G.F. and B.L. Brady. 2002. Verticillium wilts. CABI Publishing, New York, NY.

Ryder, E.J. 1991. 'Salinas 88' lettuce. HortScience 26:439-440.

Ryder, E.J. 1999. Lettuce, endive and chicory. Crop production science in horticulture series. CABI Publishing, New York, NY.

Ryder, E.J. and B.J. Robinson. 1991. 'Pacific' lettuce. HortScience 26:437-438.

Ryder, E.J. and B.J. Robinson. 1995. Big-vein resistance in lettuce: Identifying, selecting, and testing resistance cultivars and breeding lines. J. Amer. Soc. Hort. Sci. 120:741-746.

Ryder, E.J. and W. Waycott. 1998. Crisphead lettuce resistant to tipburn: Cultivar Tiber and eight breeding lines. HortScience 33:903904.

Shah, D.A. and L.V. Madden. 2004. Nonparametric analysis of ordinal data in designed factorial experiments. Phytopathology 94:33-43.

Simko, I., D. Pechenick, L.K. McHale, M.J. Truco, O.E. Ochoa, R.W. Michelmore, and B.E. Scheffler. 2009. Association mapping and marker-assisted selection of the lettuce dieback resistance gene Tvr1. BMC Plant Biol. 9:135.

Subbarao, K.V., J.C. Hubbard, A.S. Greathead, and G.A. Spencer. 1997. Verticillium wilt, p. 26-27. In: Davis, R.M., K.V. Subbarao, R.N. Raid and E.A. Kurtz (eds.). Compendium of lettuce diseases. The American Phytopathological Society, St. Paul, MN.

Vallad, G.E., R.G. Bhat, S.T. Koike, E.J. Ryder, and K.V. Subbarao. 2005. Weedborne reservoirs and seed transmission of Verticillium dahliae in lettuce. Plant Dis. 89:317-324.

Vallad, G.E., Q.-M. Qin, R.C. Grube, R.J. Hayes, and K.V. Subbarao. 2006. Characterization of race-specific interaction among isolates of $\mathrm{Ver}$ ticillium dahliae pathogenic on lettuce. Phytopathology 96:1380-1387.

Vallad, G.E. and K.V. Subbarao. 2008. Colonization of resistant and susceptible lettuce cultivars by a green fluorescent protein-tagged isolate of Verticillium dahliae. Phytopathology 98:871-885. 